\title{
A comparison of the pre-education expectations, perceptions developed through the experience, and motivation of the students taking vocational tourism education
}

\author{
ZekiAkınci $^{1}$ \\ GülserenYurcu ${ }^{2}$ \\ Murad AlpaslanKasalak ${ }^{3}$
}

\begin{abstract}
The quality of tourism education provided at vocational schools could be achieved through a two-way interaction between the school and the students. In order for tourism education provided at vocational schools aiming to train mid-level human resources for the tourism sector to be at desired quality, it is of paramount importance to know the levels of expectations, perceptions, and motivation of students, who are the most important elements of education.

This study aimed to determine students' pre-education expectations, perceptions developed in the education process and finally their motivation regarding the tourism education provided. Data were collected through questionnaires consist of a personal information and three scales (motivation, expectation and perception scales for tourism education). In this study, it was detected that the levels of expectations that 423 students receiving associate degree tourism education had prior to tourism education affected the levels of perceptions formed in the process and motivation positively. However, as a result of the fact that the expectations of the students who had high expectations prior to tourism education were not met during their experiences, their perceptions fell compared to the expectation and they had motivation at the rate of the perceptions formed. It was revealed that vocational schools were insufficient to meet student expectations.
\end{abstract}

Keywords: Expectation; Perception; Motivation; Tourism Students; Tourism Education.

\section{Introduction}

Tourism is one of the sectors which are increasing their growth rate and share in the world economies significantly with its stimulating, driving and leading effect. According to the annual report of the United Nations World Tourism Organization (UNWTO) released in 2014, in terms of export revenue, tourism sector is ranked fourth after the oil, chemistry, and food sectors (WTO, 2015b). In addition, in 2014, when we look at the place of tourism sector in the world economy, the fact that it accounts for the $30 \%$ of the service sector, provides the $6 \%$ of the world exports, employs every 1 person in 11 people, and produces the 10\% of the world income (WTO, 2015a) reveal the importance of tourism sector in the national and world economies clearly.

\footnotetext{
${ }^{1}$ Assist. Prof. Dr., Akdeniz University, Tourism Faculty, Tourism Management Department, zakinci@akdeniz.edu.tr 2 Assist. Prof. Dr., Akdeniz University, Tourism Faculty, Recreation Management Department, gulserenyurcu@akdeniz.edu.tr

3 Assist. Prof. Dr., Akdeniz University, Tourism Faculty, Recreation Management Department, muradkasalak@akdeniz.edu.tr
} 
Akınc1, Z., Yurcu, G., \& Kasalak, M. A. (2017). A comparison of the pre-education expectations, perceptions developed through the experience, and motivation of the students taking vocational tourism education. Journal of Human Sciences, 14(1), 10-23. doi:10.14687/ihs.v14i1.4364

The consistent increase in the contributions of tourism sector to the world and national economies in terms of both revenue and employment creation (Keung, 2000) has caused an increase in the competition in the national and international tourism market. The high quality of the service provided plays an important role in being successful in the tourism sector among the competing countries and achieving the targeted share of the growing tourism pie. The need for the qualified labour force that will provide quality services has increased in this process (Sem\& Clements, 1996). Labour force at the estimated quality can only be achieved through an active and high quality tourism education and training (Ünlüönen, 2000). Being able to ensure the quality of service required by today's contemporary tourism understanding and achieves quality relations between the tourist and employees serving to the tourist are largely based on the high levels of vocational and technical education of the employees working in the sector (Christou, 1999; Alp, 1992).

Vocational tourism education offered in secondary schools lasts four years as formal tourism education. Associate degree education is provided for two years at higher education institutions and students are placed to these institutions according to their diploma grades from the secondary schools providing vocational tourism education in Turkey, primarily from district schools among the secondary schools where tourism education is offered without examination. Undergraduate education at higher education institutions covers a total of four years, including eight semesters. According to the central examination system, these institutions admit students from all secondary schools.

Tourism education can be defined as helping individuals gain tourism awareness and philosophy, contributing to the development of tourism sector, training qualified staff and managers to be employed in tourism sector, and in this context, helping them comprehend the new concepts, ideas and technologies by teaching the management techniques (Amoah\& Baum, 1997; Üzümcü\&Bayraktar, 2004; Hacıoğlu, 1992; Misırl1, 2002). The educational process covering these objectives stated must have the qualities such as being economic, being preparatory to life by getting adapted to the developments, sustainability, and being society and sector-oriented (Alkan et al., 1996). In this context, learning the expectations, perceptions, and motivation levels of the students, who are the subjects of tourism education, about tourism education is of paramount importance in terms of revealing the quality of the current tourism education, identifying the shortcomings, detecting the problems and solving them.

Expectations are described as preliminary thoughts that set the standard or reference point while carrying out performance evaluation of a product. Understanding the customers' expectations of the service that is provided intangibly is the key to ensure the tangible quality of the service. Therefore, expectations play a key role in the evaluation of the service quality (Clow et al., 1997; Cronin \& Taylor, 1992; Grönroos, 1984; Lehtinen\&Lehtinen, 1982; Parasuraman et al., 1985; Tse\& Wilton, 1988).

The same case also goes for education. Identifying the expectations of students that they have created for the school they want to study at and the positive perceptions formed through the expectations that are met help students' motivation to increase. However, certain factors such as time dimension, a change in wishes and desires are changing the educational expectations over time as well. In addition, determinants like the image of the educational institution, the perceived quality of the school in the business world, the popularity of the city, socio-economic factors etc. may play an essential role in the formation of the expectations of the students. In this process, the expectations that develop prior to experiences can be reshaped in the decrease or increase direction as a result of the perceptions emerging after the experience.

The educational process includes in-class academic teaching as well as out-of-class studentinstructor relations, curriculum, and academic counselling and guidance for students. Preparing the course contents according to the current issues and sectoral requirements leads to the fulfilment of student expectations; and this situation also contributes to the increase in satisfaction from the 
Akınc1, Z., Yurcu, G., \& Kasalak, M. A. (2017). A comparison of the pre-education expectations, perceptions developed through the experience, and motivation of the students taking vocational tourism education. Journal of Human Sciences, 14(1), 10-23. doi:10.14687/ihs.v14i1.4364

educational experiences and in future motivation for vocational education. In the higher education institutions offering tourism education, the fact that vocational courses are taught practically by the experts in the field according to the students' interests and include the latest samples of technology used in the sector may contribute to the formation of student motivation by playing a significant role in fulfilling the expectations that have emerged.

Although it is a subjective concept, perception which is a reality for customers occurs as a result of its shaping human behaviours. Customers' perceptions of the product offered are influenced to a large extent both from their previous and subsequent experiences. In this context, according to Parasuman et al. (1990), perception is defined as customers' general assessment of a product. Therefore, perception is the only valid element in the evaluation of service and service quality. Because of both the values of the educational institution and the personal characteristics of the student, perception, in other words the perceived value, is a subjective condition which differs from one individual to another. In addition, cultural differences, geographical features, and several special conditions affect the perceived value. In a study, Maimunah and Finch (2009) indicate that three important factors including instructors' performance, service delivery process and activities supporting the basic process affect students' learning experiences which influence students' perception. This finding is supported by the study of Hill, Lomas and MacGregor (2003) on students' perceptions of the quality of education at tertiary level. In the same study, the quality of the instructors and the student support systems were determined to be the most influential factors on students' perceptions. Positive values emerging as a result of the interaction between the expectations indicating the expected value for the students and the perceptions indicating the actual value for them have an important role in increasing the motivation level of the students.

Many definitions have been proposed by researchers about motivation, which is an issue in which almost everyone related to education is interested and which attracts their attention. According to Yildirim (2006), motivation is expressed as "the force that starts the necessary actions to meet a need". Pintrich and Schunk (2002) define motivation as "a process in which goal-directed activity is instigated and sustained". In addition, It is also described as "an intrinsic force that prompts, directs and ensures the continuity of behaviour" (Thorkildsen et. al., 2002). Woolfolk (2004) defines motivation as "an internal state that arouses, directs and maintains behaviour". Motivation is also described as the academic engagement that is the most influential of all the factors that affect student performance (Francis et al., 2004). In all these definitions, it is clearly seen that motivation has a structure that covers inner power, permanent features, impulsive behaviours against a stimulus, and beliefs and influences. In short, motivation can be defined as a situation which all the factors that determine the extent of the willingness to participate (attempt) in an activity form or as the creation of such a situation.

Expectations related to learning and needs that have not been met play a significant role in student motivation (Prescott \& Simpson, 2004). Nevertheless, students' motivation for learning and achievement is an element that is often ignored in professional education programs. However, the motivation of individuals receiving education is the most critical component of educational programs. The only reason why even the education programs that have been designed and practiced in the best way fail is the low motivation of the students receiving the program (Çevikoğlu, 2006). Educators and school administrators usually state that students who prefer schools providing tourism education have lower motivation and success compared to students choosing other programs (Cole et al., 2006). The reasons for this low motivation can include the fact that some students might have chosen a program or a school offering tourism education by being under the influence of their parents and teachers due to the fact that they have a limited knowledge of this sector and are misinformed about the career perspectives (Lam \& Xiao, 2000).

Every educator aiming to increase academic success has to care about the motivation of their students from time to time. Motivation problems are observed to be an important and current problem area affecting academic achievement. This situation has also been identified in the studies 
Akınc1, Z., Yurcu, G., \& Kasalak, M. A. (2017). A comparison of the pre-education expectations, perceptions developed through the experience, and motivation of the students taking vocational tourism education. Journal of Human Sciences, 14(1), 10-23. doi:10.14687/ihs.v14i1.4364

carried out on the subject (Cunningham, 2003; Matuga, 2009; Renchler, 1992; Zimmerman, 1990). In a study conducted by Mak and Melody (2014), it was reported that the students expressed the elements that motivated them to choose a school providing tourism education and to receive education in this field as 'field attractiveness" and "curriculum attractiveness"; and they also stated that the most motivating factors were that receiving tourism education provided the opportunity to get a good job and self-actualization. In another study that supports these findings, Lee et al. (2008) emphasized that the basic motivation behind the preference of schools providing tourism education was the self-actualization need that meant the desire to learn and know different cultures, languages, and people. In many other studies, the main source of the motivation of the students receiving tourism education at undergraduate level was reported to be better career prospects (Airey\&Frontistis, 1997; Huyton, 1997; Kim et al., 2007; Lee et al., 2008; Lee et al., 2010; Lewis \&Airey, 2001; Zhao, 1991). In addition, the image that people working in the tourism industry have a pleasant life, tourism sector's providing the opportunity to travel all over the world, and the career opportunities motivate young people wishing to receive tourism education and the students receiving tourism education (Kim et al., 2007).

\section{Methodology}

Basic Survey Model from Quantitative approach was employed to obtain the responses of the students. The population of the research consists of 670 students receiving associate-degree tourism education at the Vocational Schools of Akdeniz University. The sample of the study comprised 423 vocational school students. Data were collected through questionnaires in the fall semester of 2015- 2016 academic year. Data collection tool invented to collect the research data comprised four sections. There are personal information (gender, the high school graduated from, their current departments, class) in the first section, Motivation for Tourism Education Scale which included 17 statements in the second section, Expectation of Tourism Education Scale which comprised 10 statements in the third section, and Perception of Tourism Education Scale which consisted of 7 statements in the fourth section. The scales used in the study were the scales that by Mak and Melody (2014) developed and used in their study. The scales translated in Turkish by the Authors of this study. A pilot study of 20 students studying the Tourism Management program of The Akdeniz University was conducted. Based on their feedback, these measurements and statements were refined. The scales used in the study were five-point likert type in the form of (1) "Completely disagree", (2) "Disagree", (3) "Neutral", (4) "Agree" and (5) "Completely agree". Data collected via the questionnaire were analyzed and interpreted through the SPSS statistical analysis software package program. According to the results of the data analysis of the study, The Cronbach's Alpha coefficient was found as 0,91 in the general validity and reliability analysis of the scales; Cronbach's Alpha coefficient was 0,88 for the Motivation for Tourism Education, it was 0,83 for the Expectation of Tourism Education, and it was 0,85 for the Perception of Tourism Education scale. These Cronbach's Alpha values indicate high reliability for the scales used in the study.

Kolmogorov-Simirnov test was carried out in order to determine whether the data were normally distributed or not in the multivariate analyses and as a result of the test, it was found out that the data had a normal distribution. Since the data obtained had a normal distribution, parametric tests were applied. Cronbach alpha reliability analysis was used to measure the reliability of the scales used in the study, including Motivation for Tourism Education Scale, Expectation of Tourism Education Scale, and Perception of Tourism Education Scale; and frequency and descriptive statistics were used for personal information. Alpha (a) model (Cronbach's Alpha Coefficient) was used in the reliability analyses of the scales applied for validity and reliability of findings. Factor analysis was performed in order to test the construct validity of the Motivation for Tourism Education scale. Kaiser-Meyer-Olkin (KMO) test was carried out to test the adequacy of the sample size and BarlettSphericity test was conducted to determine whether the variables had 
Akınc1, Z., Yurcu, G., \& Kasalak, M. A. (2017). A comparison of the pre-education expectations, perceptions developed through the experience, and motivation of the students taking vocational tourism education. Journal of Human Sciences, 14(1), 10-23. doi:10.14687/ihs.v14i1.4364

normal distribution or not. Pearson correlation analysis was carried out in order to determine the relationship between the expectation, perception, and motivation variables; and linear regression analysis was conducted to identify the effect of variables' on each other. Independent samples t-test was performed to test the $\mathrm{H} 1$ and $\mathrm{H} 3$ hypotheses, One-Way ANOVA test was used to test the H2, H4, and H5 hypotheses, Pearson correlation analysis was done to test the H6 hypothesis, and simple linear regression analysis was performed to test the $\mathrm{H} 7, \mathrm{H} 8$, and $\mathrm{H} 9$ hypotheses. In accordance with the hypotheses developed, the research model was established as in Figure 1.

The findings obtained in this research study related to students' expectations, perceptions, and motivation are as in the following.

H1: There is a statistically significant difference between the vocational school students' motivations and their gender.

H2: There is a statistically significant difference between the vocational school students' motivations and the schools they graduated from.

H3: There is a statistically significant difference between the vocational school students' motivation and their classes.

H4: There is a statistically significant difference between the vocational school students' motivation and their departments.

H5: There is a statistically significant difference between the vocational school students' motivation and their preferences.

H6: There is a positive relationship between the vocational school students' expectations, perceptions, and motivation.

H7: The expectations of vocational school students affect their perceptions positively.

H8: The perceptions of vocational school students affect their motivation positively.

H9: The perceptions of vocational school students affect the dimensions of motivation positively.

Figure 1: Study Model

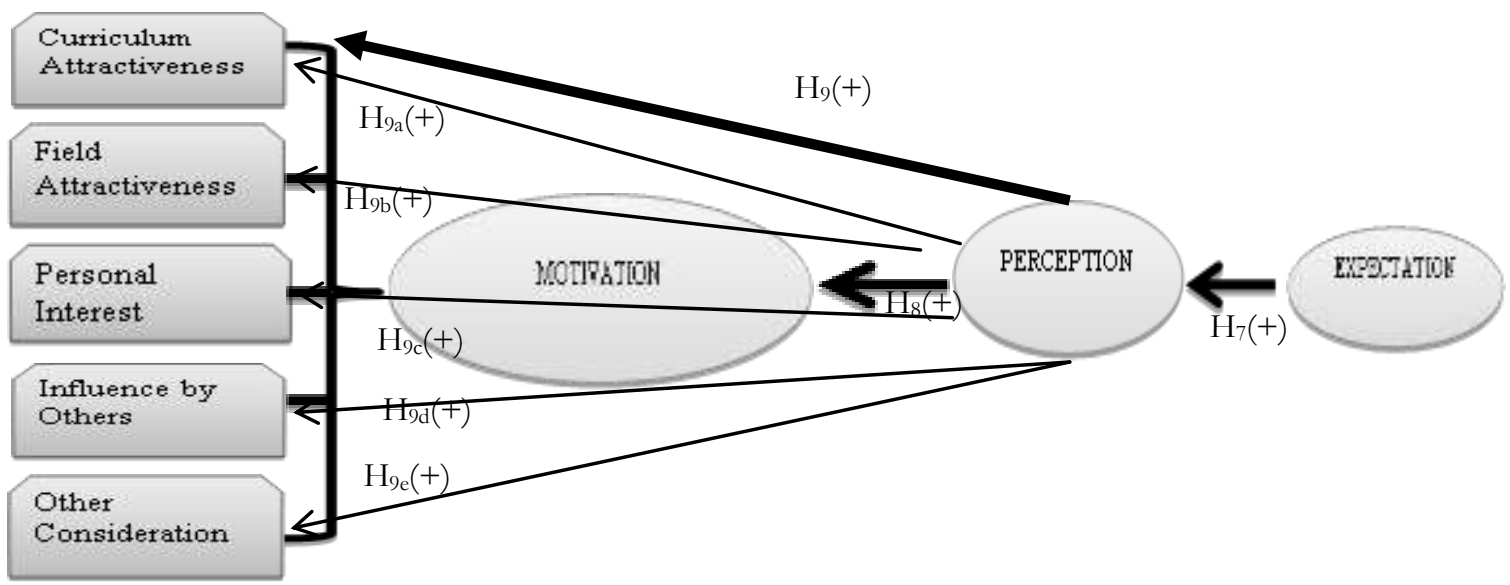

\section{Findings and Results}

KMO value of the Motivation for Tourism Education scale was 0,873, and BarlettSphericity test results were meaningful. After factor analysis and varimax rotation were carried out, four dimensions whose eigenvalue of the Motivation for Tourism Education scale was greater than one were identified and the four dimensions accounted for the $68,062 \%$ of the total variance. Table 1 shows under which factors the Motivation for Tourism Education gathered. 
Akınc1, Z., Yurcu, G., \& Kasalak, M. A. (2017). A comparison of the pre-education expectations, perceptions developed through the experience, and motivation of the students taking vocational tourism education. Journal of Human Sciences, 14(1), 10-23. doi:10.14687/ihs.v14i1.4364

Table 1. Factor analysis for motivation for tourism education

\begin{tabular}{|c|c|c|c|c|}
\hline Variables & Statements & $\begin{array}{l}\text { Factor } \\
\text { Loading }\end{array}$ & $\begin{array}{l}\text { Factor } \\
\text { Validity }\end{array}$ & $\begin{array}{l}\text { Factor } \\
\text { Variance }\end{array}$ \\
\hline $\begin{array}{l}\text { Curriculum } \backslash \\
\text { Field } \\
\text { Attractiveness }\end{array}$ & $\begin{array}{l}\text { 1-I want to work in tourism sector. } \\
\text { 2- I want to receive education in the field of tourism. } \\
\text { 3- I want to learn how tourism industry works. } \\
\text { 4- I want to learn theoretical tourism information. } \\
\text { 8- Working in tourism sector is attractive for me. }\end{array}$ & $\begin{array}{l}, 835 \\
, 866 \\
, 853 \\
, 741 \\
, 659\end{array}$ & 90 & 24,746 \\
\hline $\begin{array}{l}\text { Influence by } \\
\text { Others }\end{array}$ & $\begin{array}{l}\text { 9- The content and activities of the program where I } \\
\text { receive education are attractive for me. } \\
\text { 10-My friends like the program where we receive } \\
\text { education. } \\
\text { 11-My teachers support me in getting tourism education. } \\
\text { 12- My friends support me in getting tourism education. } \\
13-\text { My parents support me in working tourism education. }\end{array}$ & $\begin{array}{l}, 707 \\
, 791 \\
, 776 \\
, 617 \\
\end{array}$ & ,80 & 18,066 \\
\hline $\begin{array}{l}\text { Personal } \\
\text { Interest }\end{array}$ & $\begin{array}{l}\text { 5. I like tourism and travelling. } \\
6-\text { I believe my personality is suitable to receive tourism } \\
\text { education. } \\
7 \text { - I want to introduce my country to visitors in a better } \\
\text { way. }\end{array}$ & $\begin{array}{l}, 804 \\
, 737 \\
, 766\end{array}$ &, 75 & 14,511 \\
\hline $\begin{array}{l}\text { Other } \\
\text { Consideration }\end{array}$ & $\begin{array}{l}\text { 16- My academic achievement is not sufficient for me to } \\
\text { receive education in another program. } \\
\text { 17-I do not have another option. }\end{array}$ & $\begin{array}{l}, 843 \\
, 875\end{array}$ &, 71 & 10,739 \\
\hline $\begin{array}{l}\text { KMO:0,873 } \\
\text { P:,000 (Barlett's }\end{array}$ & & & Total Vr & ce: 68,062 \\
\hline
\end{tabular}

The statements which got a value below 0,50 in the factor analysis, which were "14. (Other education programs are not attractive for me) and 15. (My academic achievement is sufficient for me to receive education in this program) were excluded from the analysis. Nine statements whose factor loadings were 0,48 were not excluded because they did not cause any change in the general reliability and factor reliability. The fact that Cronbach's Alpha values for the factors are positive and also over $60 \%$ indicates that the scale is quite reliable. The motivation scale which was determined as five dimensions [Curriculum Attractiveness (4,9), Field Attractiveness (1,3,5,8), Influence by Others $(2,6,7)$, Personal Interest $(10,11,12,13)$, Other Consideration $(14,15,16,17)]$ in the study of Barry and Melody (2014) was identified as four dimensions in this study and statement distributions are displayed in Table 1. Curriculum Attractiveness and Field Attractiveness were combined as a single factor. In relation to other consideration dimension, Yong and Pearce's studies (2013:80), a factor it should have at least 3 variables, although thisdepends on the design of the study. As a general guide, rotated factors that have 2 orfewer variables should be interpreted with caution. A factor with 2 variables is only considered reliable when thevariables are highly correlated with each another $(r>.70)$ but fairly uncorrelated with other variables, may be is expressed. The validities for the dimensions of the scale were identified as ,90 in the factor of the Curriculum $\backslash$ Field Attractiveness, as ,80 in the factor of the Influence by Others, as ,75 in the factor of the Personal Interest, and as ,71 in the factor of the Other Consideration.

\section{1. Findings Concerning Personal Information}

The analysis of the participants' demographic data indicated that $61,9 \%$ of the participants were male and $38,1 \%$ of them were female. When students classes were examined, it was found out that $74,2 \%$ of the participants were in the first grade and $25,5 \%$ of them were in the second grade. In addition, $65,0 \%$ of the participants graduated from vocational high school offering tourism education, $13,2 \%$ of the students participating in the study were graduates of other high schools, $12,5 \%$ of them were graduates of Anatolian high school, and 9,2\% of the participants graduated from standard high school. The analysis of the departments of the participants indicated that $53,2 \%$ 
Akınc1, Z., Yurcu, G., \& Kasalak, M. A. (2017). A comparison of the pre-education expectations, perceptions developed through the experience, and motivation of the students taking vocational tourism education. Journal of Human Sciences, 14(1), 10-23. doi:10.14687/ihs.v14i1.4364

of the students studied at the department of Tourism and Hospitality Management,34,3\% of them were at the department of Tourism and Travel Management and 12,5\% of them were at the department of Tourism Management. When the vocational school preference order of the students was examined, it was revealed that $38,8 \%$ of the participants preferred the vocational school in the $1^{\text {st }}$ rank, $18,0 \%$ of the participants preferred it in the $2^{\text {nd }}$ rank, $10,9 \%$ of them preferred it in the $3^{\text {rd }}$ rank, $6.1 \%$ of them preferred it in the $4^{\text {th }}$ rank, and finally $4.5 \%$ of the participants preferred it in the $5^{\text {th }}$ rank.

\section{2. Findings Regarding the Research Hypotheses}

The findings and interpretations related to the research hypotheses are presented below. No difference was revealed in the mean values of the female $(\overline{\mathrm{X}}=3,655)$ and male $(\overline{\mathrm{X}}=3,723)$ students' perceptions of motivation for tourism education.

Table 2. Students difference of tourism education motivation according to gender ( $t$ test)

\begin{tabular}{lccccc}
\hline & $\mathbf{N}$ & $\overline{\mathbf{x}}$ & Std. Deviation & $\mathbf{t}$ & $\mathbf{p}$ \\
\hline Female & 158 & 3,6555 &, 65516 & $-1,005$ & \multirow{2}{*}{0,316} \\
Male & 257 & 3,7233 &, 67488 & & \\
\hline
\end{tabular}

According to the t-test carried out to determine the significance between the students' gender and their perceptions of motivation for tourism education, the difference between the students' motivation for tourism education and their genders $(t=-1,005, p>0,05)$ was not found to be significant. In this case, the hypothesis $\boldsymbol{H} \mathbf{1}$ "There is a statistically significant difference between the vocational school students' motivation and their gender.",was rejected.

Table 3. Students tourism education motivation variance analysis according to the schools they graduate (ANOVA)

\begin{tabular}{lccccc}
\hline & Sum of Squares & df & Mean Square & F & p \\
\hline Between Groups &, 185 & 3 &, 062 &, 138 &, 937 \\
Within Groups & 184,252 & 411 &, 448 & & \\
Total & 184,438 & 414 & & & \\
\hline
\end{tabular}

Table 4. Distribution of tourism education motivation score distribution according to graduated high school

\begin{tabular}{|c|c|c|c|c|c|c|c|}
\hline & & $\mathbf{N}$ & $\overline{\mathrm{X}}$ & $\begin{array}{c}\text { Std. } \\
\text { Deviation }\end{array}$ & $\begin{array}{l}\text { Std. } \\
\text { Error }\end{array}$ & Minimum & Maximum \\
\hline General High School & & 38 & 3,661 & ,64869 & ,10523 & 2,00 & 4,65 \\
\hline Anatolian High School & & 51 & 3,7096 &, 74738 & , 10465 & 2,18 & 5,00 \\
\hline $\begin{array}{l}\text { Vocational High School } \\
\text { Tourism Education }\end{array}$ & & 270 & 3,6907 & 67302 & ,04096 & 1,59 & 5,92 \\
\hline Others & & 56 & 3,7432 & ,58636 & ,07836 & 2,13 & 5,00 \\
\hline Total & & 415 & 3,6975 & ,66746 & ,03276 & 1,59 & 5,92 \\
\hline
\end{tabular}

According to the results of variance analysis (ANOVA), motivation for academic tourism education did not differ depending on the schools that students graduated from $\left.\left(\mathrm{F}_{(3 ; 411)}\right)=0,138, \mathrm{p}>0,05\right)$. As a result, the hypothesis $\boldsymbol{H} 2$ "There is a statistically significant difference between the vocational school students' motivation and the schools they graduated from.",was rejected. 
Akınc1, Z., Yurcu, G., \& Kasalak, M. A. (2017). A comparison of the pre-education expectations, perceptions developed through the experience, and motivation of the students taking vocational tourism education. Journal of Human Sciences, 14(1), 10-23. doi:10.14687/ihs.v14i1.4364

Table 5. Students difference of tourism education motivation according to their classes ( $\mathrm{t}$ test)

\begin{tabular}{lccccc}
\hline & $\mathbf{N}$ & MEAN & Std. Deviation & $\mathbf{t}$ & $\mathbf{p}$ \\
\hline $\begin{array}{l}\text { First } \\
\text { Class }\end{array}$ & 311 & 3,773 &, 66080 & & \\
$\begin{array}{l}\text { Second } \\
\text { Class }\end{array}$ & 103 & 3,457 &, 62592 & 4,256 & 0,000 \\
\hline
\end{tabular}

No statistical difference was revealed in the mean values of the first grade $(\bar{X}=3,773)$ and second grade $(\overline{\mathrm{X}}=3,457)$ students' perceptions of motivation for tourism education. It can be stated that first-grade students' motivation was higher than that of the second grade students. According to the t-test carried out to determine the significance between the students' classes and their motivation for tourism education, the difference between the students' motivation for tourism education and their classes $(\mathrm{t}=4,256, \mathrm{p}<0,00)$ was found to be significant. In this case, the hypothesis $H_{3}$ "There is a statistically significant difference between the vocational school students' motivation and their classes.",was accepted.

Table 6. Students tourism education motivation variance analysis according to their departments (ANOVA)

\begin{tabular}{lccccc}
\hline & Sum of Squares & df & Mean Square & F & p \\
\hline Between Groups & 2,345 & 2 & 1,173 & 2,653 &, 072 \\
Within Groups & 182,092 & 412 &, 442 & & \\
Total & 184,438 & 414 & & & \\
\hline
\end{tabular}

Table 7. Distribution of tourism education motivation score distribution according to their departments

\begin{tabular}{lcccccc}
\hline & N & $\bar{X}$ & $\begin{array}{c}\text { Std. } \\
\text { Deviation }\end{array}$ & $\begin{array}{c}\text { Std. } \\
\text { Error }\end{array}$ & Minimum & Maximum \\
\hline Tourism Management & 48 & 3,852 &, 64061 &, 09246 & 2,13 & 5,00 \\
Tourism and Hospitality Management & 223 & 3,634 &, 69770 &, 04672 & 1,59 & 5,92 \\
Tourism and Travel Management & 144 & 3,743 &, 61870 &, 05156 & 1,71 & 5,00 \\
Total & 415 & 3,697 &, 66746 &, 03276 & 1,59 & 5,92 \\
\hline
\end{tabular}

The results of the variance analysis carried out indicated that the students' attitudes of motivation for tourism education did not differ based on departments. The mean values of the motivation for tourism education based on departments were found as $(\overline{\mathrm{X}}=3,852)$ for the Tourism Management, as $(\overline{\mathrm{X}}=3,634)$ for the Tourism and Hospitality Management and as $(\overline{\mathrm{X}}=3,743)$ for the Tourism and Travel Management $\left.\left(\mathrm{F}_{(2 ; 412)}\right)=2,653, \mathrm{p}>0,05\right)$. Therefore, the hypothesis $\boldsymbol{H} \boldsymbol{4}$ "There is a statistically significant difference between the vocational school students' motivation and their departments.",was rejected.

Table 8. Students tourism education motivation variance analysis according to their preferences (ANOVA)

\begin{tabular}{lccccc}
\hline & Sum of Squares & df & Mean Square & F & p \\
\hline Between Groups & 8,062 & 19 &, 424 &, 950 & \multirow{2}{*}{, 521} \\
Within Groups & 165,302 & 370 &, 447 & & \\
Total & 173,364 & 389 & & & \\
\hline
\end{tabular}


Akınc1, Z., Yurcu, G., \& Kasalak, M. A. (2017). A comparison of the pre-education expectations, perceptions developed through the experience, and motivation of the students taking vocational tourism education. Journal of Human Sciences, 14(1), 10-23. doi:10.14687/ihs.v14i1.4364

Table 9. Distribution of tourism education motivation score distribution according to their preferences

\begin{tabular}{lcccccc}
\hline & $\mathbf{N}$ & $\overline{\mathrm{X}}$ & $\begin{array}{c}\text { Std. } \\
\text { Deviation }\end{array}$ & $\begin{array}{c}\text { Std. } \\
\text { Error }\end{array}$ & Minimum & Maximum \\
\hline $1^{\text {st }}$ & 160 & 3,703 &, 69258 &, 05475 & 1,59 & 5,92 \\
$2^{\text {nd }}$ & 75 & 3,730 &, 69448 &, 08019 & 1,82 & 5,00 \\
$3^{\text {rd }}$ & 44 & 3,572 &, 62736 &, 09458 & 2,00 & 5,00 \\
$4^{\text {th }}$ & 26 & 3,712 &, 63516 &, 12456 & 2,18 & 5,00 \\
$5^{\text {th }}$ & 19 & 3,791 &, 58579 &, 13439 & 2,24 & 4,65 \\
Total & 390 & 3,701 &, 66758 &, 03380 & 1,59 & 5,92 \\
\hline
\end{tabular}

According to the ANOVA result, it was revealed that students' attitudes of motivation for tourism education did not differ based on their department preference order. Students' preference order indicated that the mean value was found as $(\overline{\mathrm{X}}=3,7030)$ for the students who preferred their department in the $1^{\text {st }}$ rank, as $(\bar{X}=3,7301)$ for the students who preferred their department in the $2^{\text {nd }}$ rank, as $(\overline{\mathrm{X}}=3,5729)$ for the ones preferring their department in the $3^{\text {rd }}$ rank, as $(\overline{\mathrm{X}}=3,7127)$ for the ones who preferred their department in the $4^{\text {th }}$ rank, and it was $(\overline{\mathrm{X}}=3,7912)$ for the students who preferred their department in the $5^{\text {th }}$ rank. In this case, the hypothesis $\boldsymbol{H 5}$ "There is a statistically significant difference between the vocational school students' motivation and their preferences.",was rejected.

Table 10 indicates the relationship between students' tourism education expectations, perceptions, and motivation.

Table 10. The relationship between students' tourism education expectations, perceptions, and motivation

\begin{tabular}{lccclcl}
\hline Scale & $\mathrm{N}$ & $\overline{\mathrm{X}}$ & $\mathrm{St}$ & 1 & 2 & 3 \\
\hline 1. Expectation of Tourism Education & 415 & 3,948 &, 65444 & 1 & & \\
\hline 2. Perception of Tourism Education & 414 & 3,644 &, 82805 & $\begin{array}{l}, 515^{* *} \\
, 000\end{array}$ & 1 & \\
\hline 3. Motivation for Tourism Education & 415 & 3,697 &, 66746 &, $546^{* *}$ &, $488^{* *}$ & 1 \\
\hline
\end{tabular}

The relationship between expectation of tourism education, perception of tourism education, and motivation for tourism education was examined through Pearson's correlation technique. In the correlation table, it can be seen that the mean values were found as $(\bar{X}=3,948)$ for the expectation of tourism education, as $(\overline{\mathrm{X}}=3,644)$ for the perception of tourism education, as $(\bar{X}=3,697)$ for the motivation for tourism education. The mean values indicated that the mean value of the other consideration dimension was higher than the mean values of the other variables. There is a positive relation between the expectation of tourism education and the perception of tourism education (expectation tourism education $(\mathrm{r}=.515, \mathrm{p}<0,01))$. In addition, there is a positive relation between the motivation for tourism education and the expectation of tourism education (Motivation for tourism education $(\mathrm{r}=, 546, \mathrm{p}<0,01)$. Considering these results, students' tourism education expectations and perceptions are positively related with their motivation; that is their satisfaction increases or decreases in line with their expectations and perceptions. In this context, 
Akınc1, Z., Yurcu, G., \& Kasalak, M. A. (2017). A comparison of the pre-education expectations, perceptions developed through the experience, and motivation of the students taking vocational tourism education. Journal of Human Sciences, 14(1), 10-23. doi:10.14687/ihs.v14i1.4364

the hypotheses $\mathbf{H} 6$ 'There is a positive relationship between the vocational school students' expectations, perceptions, and motivation.”,was accepted.

The effect of students' tourism education expectations on their perception of tourism education is shown in Table 11.

Table 11. The impact of tourism education expectation on perception of tourism education

\begin{tabular}{|c|c|c|c|c|c|c|c|}
\hline \multirow{2}{*}{ Dependent Variable } & \multirow{2}{*}{ Independent Variable } & & \multicolumn{2}{|c|}{ Coefficient } & \multirow{2}{*}{$\mathrm{t}$} & \multirow{2}{*}{$\mathrm{F}$} & \multirow{2}{*}{$\mathrm{R}^{2}$} \\
\hline & & & $\beta$ & S. Error & & & \\
\hline \multirow[b]{2}{*}{$\begin{array}{l}\text { Perception } \\
\text { Education }\end{array}$} & Fixed Value & & 1,004 & ,219 & & & \\
\hline & $\begin{array}{l}\text { Expectation } \\
\text { Education }\end{array}$ & Tourism & 668 & ,055 & 12,197 & 148,766 & 0,265 \\
\hline
\end{tabular}

According to the t-test results presented in Table 11, the $\mathrm{F}$ value $(148,766)$ shows that our model is significant as a whole at all levels (Sig.=,000). It is seen from the statistical t values of the parameters that each variable included in the model is individually significant $(5 \%$ significance level). The expectation of tourism education with a $B$ value $(, 668)$ affects perception of tourism education positively. This means that when students' expectations of tourism education increase, their perceptions will increase as well. The expectation level, which affects the perception of tourism education, explains the level of perception at the rate of $0,265\left(R^{2}=0,265\right)$. According to this result, the $26 \%$ of change in the perception of tourism education is explained by the expectation of tourism education variable. In this case, the hypothesis $\mathbf{H 7}$ " $\boldsymbol{T}$ he expectations of vocational school students affect their perceptions positively.", was accepted.

The effect of students' perception of tourism education on their motivation for tourism education is shown in Table 11.

Table 12. The impact of perception of tourism education on motivation for tourism education

\begin{tabular}{|c|c|c|c|c|c|c|}
\hline \multirow{2}{*}{ Dependent Variable } & \multirow{2}{*}{$\begin{array}{l}\text { Independent } \\
\text { Variable }\end{array}$} & \multicolumn{2}{|c|}{ Coefficient } & \multirow[b]{2}{*}{$\mathrm{t}$} & \multirow{2}{*}{$\mathrm{F}$} & \multirow{2}{*}{$\mathrm{R}^{2}$} \\
\hline & & $\beta$ & S. Error & & & \\
\hline $\begin{array}{l}\text { Motivation for } \\
\text { Education }\end{array}$ & Fixed Value & 2,275 & 129 & 11,356 & 128,967 & 0,238 \\
\hline
\end{tabular}

According to the t-test results demonstrated in Table 12, the $\mathrm{F}$ value $(128,967)$ indicates that our model is significant as a whole at all levels $($ Sig. $=, 000)$. It is seen from the statistical $t$ values of the parameters that each variable included in the model is individually significant $(5 \%$ significance level). The perception of tourism education with a $\beta$ value $(, 391)$ affects motivation for tourism education positively. This means that when students' perceptions of tourism education increase, their motivation will increase as well. The perception level, which affects students' motivation for tourism education, explains the level of motivation at the rate of $0,238\left(R^{2}=0,238\right)$. According to this result, the $23 \%$ of change in the motivation is explained by the perception of tourism education variable. In this case, the hypothesis $\mathbf{H} 8$ "The perceptions of vocational school students affect their motivation positively.",was accepted. 
Akınc1, Z., Yurcu, G., \& Kasalak, M. A. (2017). A comparison of the pre-education expectations, perceptions developed through the experience, and motivation of the students taking vocational tourism education. Journal of Human Sciences, 14(1), 10-23. doi:10.14687/ihs.v14i1.4364

Table 13. The impact of perception of tourism education on the dimensions of motivation for tourism education

\begin{tabular}{|c|c|c|c|c|c|c|}
\hline \multirow[t]{2}{*}{ Dependent Variable } & \multirow{2}{*}{$\begin{array}{l}\text { Independent } \\
\text { Variable }\end{array}$} & \multicolumn{2}{|c|}{ Coefficient } & \multirow[t]{2}{*}{$\mathrm{t}$} & \multirow[t]{2}{*}{ F } & \multirow[t]{2}{*}{$\mathrm{R}^{2}$} \\
\hline & & $\beta$ & S. Error & & & \\
\hline Curriculum Attractiveness \ & Fixed Value & 2,629 & ,197 & & & \\
\hline Field Attractiveness & $\begin{array}{l}\text { Perception of } \\
\text { Tourism Education }\end{array}$ &, 356 & 053 & 6,740 & 45,434 & 0,099 \\
\hline \multirow[t]{2}{*}{ Influence By Others } & Fixed Value & 1,622 & ,163 & & & \\
\hline & $\begin{array}{l}\text { Perception of } \\
\text { Tourism Education }\end{array}$ &, 538 & 044 & 12,370 & 153,012 & 0,271 \\
\hline \multirow[t]{2}{*}{ Personal Interest } & Fixed Value & 3,473 & ,155 & & & \\
\hline & $\begin{array}{l}\text { Perception of } \\
\text { Tourism Education }\end{array}$ & ,219 & 041 & 5,290 & 27,981 & 0,064 \\
\hline \multirow[t]{2}{*}{ Other Consideration } & Fixed Value & 1,506 & 255 & & & \\
\hline & $\begin{array}{l}\text { Perception of } \\
\text { Tourism Education }\end{array}$ & ,394 &, 068 & 5,764 & 33,228 & 0,075 \\
\hline
\end{tabular}

The $\mathrm{F}$ values obtained in the $\mathrm{t}$-tests carried out indicate that the models were significant as a whole at all levels (Sig.=,000). It is seen from the statistical $t$ values of the parameters that each variable included in the model is individually significant (5\% significance level). The influence by others dimension whose $B$ value was found as $(, 538)$ was the dimension that was affected by perception most. Students' perception levels explain the dimension of Curriculum \Field Attractiveness at the rate of $0,099\left(\mathrm{R}^{2}=0,099\right)$, the dimension of Influence by Others at the rate of $0,271\left(R^{2}=0,271\right)$, the dimension of personal interest at the rate of $0,064\left(R^{2}=0,064\right)$, and the dimension of Other Consideration at the rate of $0,075\left(\mathrm{R}^{2}=0,075\right)$. According to this result, the $9 \%$ of the change in the dimension of curriculum $\backslash$ field attractiveness, the $27 \%$ of change in the dimension of influence by others, the $6 \%$ of change in the dimension of personal interest, and the $7 \%$ of the change in the dimension of other consideration are explained by the perception of tourism education variable. Curriculum Attractiveness and Field Attractiveness were combined as a single factor as a result of the factor analysis. In this case, the hypotheses $\boldsymbol{H}^{\boldsymbol{9}}$ "The perceptions of vocational school students affect the dimensions of motivation positively.",was accepted.

\section{Discussion and Conclusion}

According to findings of this study, no differences were detected in the mean values of the students' gender and motivation for tourism education. When the students' motivation perceptions of tourism education was examined in terms of their classes, it was found out that there were statistically significant differences and that the first-grade students' motivation was higher than that of the second-grade students. However, no difference was revealed between the students' motivation perceptions of tourism education based on the departments where they received tourism education at the vocational school. In addition, it was also identified that students' preference order of the programs offering tourism education at the vocational school did not cause any differences in their motivation for tourism education.

When the relationship between the expectation of tourism education, perception of tourism education and motivation was examined, it was revealed that there was a positive relation between the vocational school students' expectations and perceptions, and also between their perceptions and motivation. After the analysis of the findings obtained related to the variables, it was detected that the expectation, perception and motivation model that we created was significant as a whole at all levels and that the variables affected each other positively. In addition, it was indicated that due to the fact that the school could not determine and/or meet the expectations of the students throughout the educational experience, the perceptions of the students who had high expectations 
Akınc1, Z., Yurcu, G., \& Kasalak, M. A. (2017). A comparison of the pre-education expectations, perceptions developed through the experience, and motivation of the students taking vocational tourism education. Journal of Human Sciences, 14(1), 10-23. doi:10.14687/ihs.v14i1.4364

of tourism education prior to the education process decreased partially compared to their expectations and the students had a level of motivation that was parallel to the perceptions developed. In this regard, students' motivation for tourism education is shaped depending on the perceptions developed. In this study, it was seen that the vocational schools of higher education fell short to determine and meet the current expectations of the students. The results of this study are parallel with previous research of Hill, Lomas and MacGregor (2003) and Maimunah and Finch (2009) that found students' expectations and perceptions have an important influence on students' motivation.

The quality of the services offered can make a difference between the enterprises in the tourism sector where generally similar touristic products (e.g. sea, sand, and sun) are presented and an intense competition is experienced. The quality of human resources is of paramount importance in the quality of the service offered. Schools offering tourism education play an important role in providing quality human resources to the tourism sector. Schools providing tourism education should firstly have information about the students' expectations related to the tourism education that is provided, their perceptions developed in the process and finally their motivation in order for them to be able to carry out the mission incumbent upon them to train the quality human resources required by the tourism industry.

In accordance with the data obtained, identifying and satisfying the expectations of the students who prefer and come to vocational high schools to receive tourism education is of great importance in terms of increasing student motivation. The expectations formed as a result of the effects of several factors (parents, teachers, friends, industry experience, media, school image, etc.) create a conscious or unconscious bias on students; and the students with low expectations of tourism education have low perceptions and motivation, the students with high expectations of tourism education have high perceptions and motivation.

\section{Recommendations}

The quality of tourism education in the real sense can be achieved through a two-way interaction. On the one hand schools want offer better tourism education services and to produce better students must have the means to provide quality services and must struggle to meet and even exceed the expectations, on the other hand, students who come to schools to get tourism education must be conscious and have high expectations. In this context, vocational schools of higher education providing tourism education must improve its school-sector, media, and public relations and cooperation and give the necessary importance to public relations activities for tourism vocational high schools that constitute the student resource and for other high schools.

As in any research, a number of limitations require a more careful evaluation of the research results in this study as well. This study carried out in vocational high schools of a university cannot be generalized, but the findings obtained are expected to contribute to future research. There is no doubt that this study should be carried out again with more detailed studies including more schools and more students by conducting this research in other schools that provide tourism education.

\section{References}

Airey D, Frontistis A (1997). Attitudes to careers in tourism: An Anglo Greek compare. Tourism Management, 18(3): 149-158.

Alkan C, Doğan H, Sezgin İ (1996).MeslekîveTeknikEğitiminEsaslar: Kavramlar, Gelişmeler, Uygulamalar, Yönelmeler. Ankara, GaziBüroKitabevi.

Alp T (1992).Türkiye`deTurižmĔ̈itimin Yapısı, UygulananPolitikalarveSonuclar, TurizmEğitimi, Ankara, TurizmBakanllğıTurizmEğitimiGenelMüdürlüğü, YorumBasımYayınSanayiTicaretŞirketi: 47.

Amoah V A, Baum T (1997). Tourism education: policy versus practice. International Journal of Contemporary Hospitality Management, 9(1): 5 - 12. 
Akınc1, Z., Yurcu, G., \& Kasalak, M. A. (2017). A comparison of the pre-education expectations, perceptions developed through the experience, and motivation of the students taking vocational tourism education. Journal of Human Sciences, 14(1), 10-23. doi:10.14687/ihs.v14i1.4364

Christou E (1999). Hospitality Management Education In Greece: An Exploratory Study. Tourism Management, 20(6): 683-691.

Clow K E, Kurtz D L, Ozment J, Ong B S (1997). The Antecedents of Consumer Expectations of Services: An Emprical Study Across Four Industries. The Journal of Services Marketing, 11(4): 230-248.

Cole J S, Cole S T, Ferguson A P (2006). Students' motivation to learn: A comparison between undergraduate students majoring in Parks, Recreation and Tourism and those in other majors. Journal of Teaching in Travel and Tourism, 6(2): 57-66.

Cronin Jr J J, Taylor S A (1992).Measuring Service Quality: A Reexamination and Extension.Journal of Marketing, 56: 55-68.

Çevikoğlu S (2006). TrafikentSürücüË̆itimSimülatörününSimülatörÖzellikleri ARCS MotivasyonModeliBakımmndanDeğerlendirilmesiveS ürü̈ülerinDireksiyonEğitimiBaşarsma Etkisi.GaziÜni versitesi, BasılmamışYüksekLisans'Tezi.

Cunningham G K (2003).Can education schools be saved? From $<$ http://www.vestibular.uerj.br/vest2004/files / 2004ef d1 ing.pdf $>$ (Retrieved on February 19, 2016).

Francis A, Goheer A, Haver-Dieter R, Kaplan D, Kerstetter K, Kirk M et al. (2004). Promoting academic acbievement and motivation: A discussion \& contemporary issues based approach. Gemstone Program thesis, University of Maryland, United States.

Grönroos C (1984). A Service Quality Model and Its Marketing Implications.European Journal of Marketing, 18(4): 36-44.

Hacioğlu N (1992). YüksekögretimdeMeslekiTurizmEğitimiGelistirmePerspektifleri. TurizmEğitimi, Ankara, TurizmBakanlığıTurizmEğitimiGenelMüdürlüğü, Yorum Basın Yayın San. Ltd. Şti.: 92.

Hill Y, Lomas L, MacGregor J (2003). Students' perceptions of quality in higher education.Quality Assurance in Education, 11(1): 15-20.

Huyton J R (1997). The implications of cross-cultural communication in the hotel industry: A Chinese case. Proceedings of the 7th National Tourism and Hospitality Research Conference. Sydney: Bureau of Tourism Research.

Keung S W (2000). Tourist's Perception of Hotel Frontline Employess' Questionable Job-related Behaviour. Tourism Management, 21(2): 121-134.

Kim S, Guo Y, Wang K, Agrusa J (2007). The Study Motivations and Study Preferences of Student Groups from Asian Nations Majoring in Hospitality and Tourism Management Programs.Tourism Management, 28(1): 140-151.

Lam T, Xiao H (2000). Challenges and constraints of hospitality and tourism education in China.International Journal of Contemporary Hospitality Management, 12: 291-295.

Lee M J, Kim S, Lo A (2008). Perceptions of hospitality and tourism students towards study motivations and preferences: A study of Hong Kong students. Journal of Hospitality, Leisure, Sport and Tourism Education, 7(2): 45-58.

Lee M, Olds D, Lee C (2010). Why students choose a hospitality and tourism program: A pilot study of U.S. undergraduate students. Journal of Hospitality \& Tourism Education, 22(3): 20-26.

Lehtinen U, Lehtinen J R (1982). Service Quality: A Study of Quality Dimensions. Unpublished Working Paper, Helsinki: Service Management Institute.

Lewis A, Airey D (2001). Tourism careers in Trinidad and Tobago: Perceptions of secondary school students. Tourism and Hospitality Research, 3(1): 7-20.

Maimunah S, Kaka A, Finch E (2009) .Factors That Influence Student's Level of Satisfaction With Regards To Higher Educational Facilities Services. Malaysian Journal of Real Estate 4(1): 34-51.

Mak B L M, Melody M L Ng (2014). Motivations, Expectations, Perceptions, and Preferences in Secondary School Tourism and Hospitality Curriculum.Journal of Teaching in Travel and Tourism, 14 (3): 260-281. 
Akınc1, Z., Yurcu, G., \& Kasalak, M. A. (2017). A comparison of the pre-education expectations, perceptions developed through the experience, and motivation of the students taking vocational tourism education. Journal of Human Sciences, 14(1), 10-23. doi:10.14687/ihs.v14i1.4364

MatugaJ M (2009). Self-regulation, goal orientation, and academic achievement of secondary students in online university courses.Educational Technology \&Society, 12 (3): 4-11.

Misırlı İ (2002).TurizmSektöründeMeslekStandartlarıveMeslekiBelgelendirmeSistemi (Sertifikasyon). Anatolia Turizm ArasttrmaDergisi, 13(1): 39-55.

Parasuraman A, Zeithaml V A, Berry L L (1985). A Conceptual Model of Service Quality and Its Implications for Future Research.Journal of Marketing, 49: 41-50.

Parasuraman A, Berry L L, Zeithaml V A (1990). Guidelines for Conducting Service Quality Research.Journal of Marketing Research, 66(2): 34-44.

Pintrich P R, Schunk D H (2002). Motivation in education: Theory, research, and applications (2nd ed.). New Jersey: Prentice Hall.

Prescott A, Simpson E (2004). Effective Student Motivation Commences with Resolving 'Dissatisfiers. Journal of Further and Higher Education, 28(3): 247-259.

Renchler R (1992). Student motivation, school culture, and academic achievement. ERIC/CEM Trends and Issues Series, Number 7, USA.

Sem J, Clements C (1996). Tourism and Recreation Management: Strategies for Public Lands. Parks and Recreation, 31(9): 92-105.

Thorkildsen T A, Nicholls J G, Bates A, Brankis N, DeBolt T (2002). Motivation and the struggle to learn: responding to fractured experiences. Boston, Massachusetts: Allyn and Bacon.

Tse D K, Wilton P C (1988). Models of Consumer Satisfaction Formation: An Extension. Journal of Marketing Research, 25 (2): 204-212.

Ünlüönen

$\mathrm{K}$

(2000).

TurizmİsletmeciliğiÖğretmenlikProgramlarınınÖğrenciBeklentileriVeAlgılamalarıAçısındanD eğerlendirilmesi.GazįÜniversitesi TicaretveTurižnĔ̈itimFakültesiDergisi, 3: 218-238.

Üzümcü $\quad \mathrm{T} \quad \mathrm{P}, \quad$ BayraktarS Türkiye'de'TurizmOtelİşletmeciliğiAlanındaĔ̆itimVerenYüksekÖğretimKuruluşlarındakiEğit imcilerinTurizmMeslekiEğitimininEtikselAçıdanİncelenmesineYönelikBir Alan Araştırması. 3.UlusalBilgi, EkonomiveYönetimKongresi, BildiriKitabi: 80.

WTO (2015a).From < http://www2.unwto.org/content/why-tourism.> (Retrieved on April 15 2016).

WTO (2015b). Annual Report 2015.Published by the World Tourism Organization, Madrid, Spain.

Yıldırım O Ş (2006).AnadoluGüzelSanatlarLiseleriÇalgıĔ̈itimindeMotivasyon. DokuzEylü̈ÜniversitesiBucaĔ̈itimFakültesiDergisi, 20: 130-136.

Yong A G, Pearce S (2013) A beginner's guide to factor analysis: focusing on exploratory factor analysis. Tutorials in Quantitative Methods for Psychology, Vol. 9(2):79-94.

Zhao J L (1991). A current look at hospitality and tourism education in China's colleges and universities.International Journal of Hospitality Management, 10(4): 357-367.

Zimmerman B J (1990). Self-regulated learning and academic achievement: An overview. Educational Psychologist, 25(1): 3-17.

Woolfolk A E (2004). Educationalpsychology. (9th ed.). New York: Pearson. 